\title{
Editorial
}

\section{CATEgORIAS ESPECÍfICAS DE PESSOAL De ENFERMAGEM}

A autarquia formada pelos Conselhos Federal e Regionais de Enfermagem está realizando trabalho de alta significação social no país.

Para a inscrição nos Conselhos Regionais de Enfermagem, são categorias específicas de pessoal de enfermagem, as seguintes:

no QUADRO I, com carteira de cor verde: categoria de enfermeiro e obstetriz:

no QUADRO II, com carteira de cor azul, o técnico de enfermagem;

no QUADRO III, cam carteira de cor vermelha, a categoria de auxiliar de enfermagem; e ainda as categorias de prático de enfermagem e parteira prática com certificado obtido, nos termos de leis, até 1964, ano em que cessaram os exames para esses certificados.

Essas categorias são reguladas por lei e constam da Resolução COFEN - 4, publicada no Diário Oficial da União de 15/08/75, Seção I - Parte II, pág. 3015 - 16.

O Conselho Federal de Enfermagem tem ainda que atentar para outros que fazem parte do pessoal de enfermagem, além das categorias acima descritas, uma vez que a Let $\Omega^{\circ} 5.905$, de 12 de julho de 1973, em seu artigo $2 .^{\circ}$ refere-se a "compreendidas nos serviços de enfermagem." Foi sábia a lei. Atualmente a maioria dos ativos nos serviços de enfermagem é de pessoas que não têm ocupação protegida por lei de exercício; são atendentes de enfermagem, visitadores sanitários e instrumentadores cirúrgicos. Estes três grupos não terão inscrição, com carteira; terão Carta de Provisão, e serão denominados provisionados.

Para o provisionamento de atendentes de enfermagem, visitadores sanitários e instrumentadores cirúrgicos, isto é, das categorias não reguladas em lei, nem de ensino nem de exercício, o Conselho Federal de Enfermagem estabeleceu que formarão três categorias específicas de ocupações, que são as já referidas neste parágrafo. O Diário Oficial da União de 25 de agosto de 1976, à pág. 3422, publicou essa Resolução.

Discute-se, daqui por diante, neste editorial, as consequências, para as pessoas, desses atos mencionados.

Primeiramente, cada um deve tomar posse, prontamente, do seu lugar. Faz-so um apelo a cada um para divulgar, ao máximo, a obrigatoriedade da inscrição ou provisionamento, conformo for o caso, de todo o pessoal de en- 
fermagem. Os que deram entrada a seus documentos nos Conselhos Regionais de Enfermagem (COREN) já são 65.058 pessoas em todo o país, segundo a estatística de 20 de setembro de 1976. O grande grufo scial do pessoal de enfermagem deve cuidar de si para que tenha condições melhores para cuidar dos outros, isto é, para poder trabalhar em boas condições.

Em segundo lugar, cada um deve olhar para cima, para descobrir em que direção poderá progredir. Daqui desse editorial aponta-se o caminho a seguir: dar de si a máxima, a mais profunda, a mais autêntica e a mais conscienciosa contribuição em seu trabalho. $E$, ainda, no tempo disponivel que por via correta, puder conseguir. tratar de fazer o curso de uma ccupação de saúde mais altamente categorizada. Muitos farão o curso de graduação de enfermeiro e alguns, de medicina. Outros procurarão o curso de técnico de enfermagem. A carga horária desse curso, para obtenção do diploma de técnico de enfermagem, dá a facilidade de a sua duração ser de pouco mais de um ano, para os que já concluiram o curso de $2 .^{\circ}$ grau, secundário. Muitos outros desejarão fazer o curso de auxiliar de enfermagem; esse tipo de curso' é o que existe em maior número, no país.

Os ocupantes das três categorias não reguladas em lei, isto é, atendentes de enfermagem, visitadores sanitárıos e instrumentadores cirúrgícos, são os que necessitam, com mais urẾncia, de melhora ocupacional. Convirá a estes procurar obter título de uma das categorias de enfermagem reguladas por lei, aqui ciladas. Haverá dificuldades, em virtude quer de obrigações da vida ae familia e cuidado de filhos quer de meios financeiros. $O$ difícil não é o impossivel.

No mundo inteiro o pessoal de enfermagem cuida de progredir. O Conselko Internacional de Enfermeiros guia os enfermeiros nos principios do progresso ocupacional para todo o pessoal de enfermagem. A Organização Internacional do Trabalho ocupa-se dessas categorias de enfermagem de modo especial, pelo motivo da necessidade de atenção a esse grande grupo de pessoas que, em todos os paises, contribuem para o bem-estar humano. (HGD) 